\title{
PROFESIONALISME GURU MENANAMKAN KETERAMPILAN PROSES SAINS DALAM MATERI IPA PADA SISWA KELAS V MI MA'ARIF BEGO
}

\section{TEACHERS' PROFESSIONALISM IN INSTILLING SCIENCE PROCESS SKILL ON NATURAL SCIENCE LESSON (IPA) TO THE FIFTH GRADE STUDENTS AT MI MA'ARIF BEGO}

\author{
Niswatun Hasanah ${ }^{1}$, Verliyanti $^{2}$, Mohamad Agung Rokhimawan ${ }^{3}$ \\ ${ }^{1,2}$ Pascasarjana UIN Sunan Kalijaga Yogyakarta \\ ${ }^{3}$ Fakultas Ilmu Tarbiyah dan Keguruan UIN Sunan Kalijaga Yogyakarta \\ 1,2,3 Jl. Laksda Adisucipto, Papringan, Caturtunggal, Kabupaten Sleman, DIY 55281 \\ Email: hasanahniswatun48@ gmail.com ${ }^{1}$, verliyanti24@gmail.com ${ }^{2}$, \\ rokhimawan78@gmail.com ${ }^{3}$
}

Submitted: 25-12-2019, Revised: 28-04-2020, Accepted: 28-05-2020

\begin{abstract}
Abstrak
Penelitian ini bertujuan untuk mengetahui professionalisme guru dalam menanamkan keterampilan proses sains di MI Ma'arif Bego. Penelitian ini merupakan penelitian kualitatif. Data diperoleh melalui observasi, wawancara, dan dokumentasi y ang diuji keabsahan dan validitasnya. Jenis analisis data menggunakan model Miles dan Huberman yaitu reduksi data, penyajian data, dan pengambilan kesimpulan. Temuan dalampenelitian iniadalah (1) des ain perencanaan pembelajaran guru sudah memuat keterampilan proses sains dan (2) implementasi pembelajaran di kelas telah menanamkan keterampilan proses sains pada aspek observasi, klasifikasi, pengukuran, inferensi, prediksi, dan komunikasi. Unsurketerampilan proses sains yang dominan muncul dalam proses pembelajaran di kelas yaitu mengobservasi, mengkomunikasikan, dan mengklasifikasikan.
\end{abstract}

Kata Kunci: Profesionalisme Guru, Keterampilan Proses Sains, Pembelajaran IPA

\begin{abstract}
This study aimed to find out the teachers 'professionalism in instilling science process skill in MI Ma'arifBego. This research used qualitative method. The data obtained throughobservation, interview, and documentation that had been tested the validity. The data analysis used was Miles and Huberman model i.e data reduction, presentation, and conclusion. The findings in this study indicated that (1) the design of the teachers' learning plan has included science process skill and (2) learning implementation in the class has instilled science process skill to the observation, classification, measurement, inference, prediction, and communication aspects. The dominant elements of science process skill in classroom learning were observing, communicating, and classifying.
\end{abstract}

Keywords: Teacher Professionalism, Science Process Skill, Natural Science Lesson

How to Cite: Has anah, N., Verliy anti, \& Rokhimawan, M. A. (2020). Profesionalisme Guru Menanamkan Keterampilan Proses Sains dalam Materi IPA pada Sis wa Kelas VMI Ma'arif Bego. AULADUNA: Jumal Pendidikan Dasar Islam, 7(1), 1-9. 


\section{Pendahuluan}

Undang-Undang Republik Indonesia Nomor 14 Tahun 2005 tentang guru dan dosen, Bab IV pasal 8 yang berbunyi seorang guru wajib memiliki kompetensi serta kemampuan dalam mewujudkan tujuan pendidikan nasional. Adapun kompetensinya yaitu kompetensi kepribadian, pedagogik, profesional, dan kompetensi sosial. Empat macam kompetensi tersebut harus dipadukan supaya menjadi satu kesatuan yang utuh dalam suatu pembelajaran. Pendidikan membantu mengembangkan potensi dan keterampilan yang dimiliki siswa dan juga dapat digunakan dalam menjalani hidup di masyarakat, bangsa, dan negara. Keterampilan yang diharapkan salah satunya keterampilan proses sains (Elvanisi, Hidayat, \& Fadillah, 2018).

Penelitian ini membahas tentang profesionalisme guru dalam pembelajaran IPA, terutama tentang penanaman keterampilan proses sains pada pembelajaran. Dalam suatu pembelajaran IPA, siswa tidak cukup hanya mengetahui konten materi semata tetapi bisa mempraktikannya secara langsung karena IPA merupakan suatu ilmu yang identik dengan kehidupan alam. Pada pembelajaran IPA, seyogianya mengaplikasikan empat unsur yang terdapat dalam pembelajaran IPA sekolah dasar, yaitu IPA sebagai produk, proses, aplikasi, dan sikap. Jika siswa dapat memahami empat unsur dasar ini, maka siswa tidak hanya menguasai materi atau konten saja tetapi siswa juga mampu memahami suatu proses dari konsep yang telah ada dan juga mengetahui fungsi dari suatu kejadian atau peristiwa yang dipelajari. Oleh sebab itu, walaupun dalam pembelajaran IPA sering dilakukan di dalam ruangan kelas, siswa tetap diharapkan mampu menguraikan keempat konsep tersebut, agar dapat menimbulkan rasa ingin tahu yang besar, lebih aktif, dan semangat dalam pembelajaran. Dalam pelaksanaan keempat konsep IPA tersebut, guru membutuhkan pengetahuan dan pemahaman tentang keterampilan proses sains agar guru dapat menanamkannya kepada siswa. Hal ini berkaitan dengan proses keterampilan sains yang mendukung agar pembelajaran IPA berjalan dengan baik sesuai dengan yang telah direncanakan, agar siswa dapat mengembangkan sendiri suatu fakta atau konsep serta menanamkan sikap yang dibutuhkan dalam suatu penemuan ilmu pengetahuan melalui mengembangkan keterampilan proses sains (Prasasti, 2018).

Menurut Hasanah \& Utami (2017), keterampilan proses merupakan seperangkat keterampilan yang dimanfaatkan oleh para ilmuan dalam melakukan suatu investigasi. Keterampilan proses juga merupakan suatu keterampilan yang diperoleh dari latihan kemampuan mental, fisik, dan sosial yang mendasar, sudah dikembangkan, dan telah terlatih sehingga para ilmuan menemukan dan menciptakan sesuatu hal yang baru. Keterampilan proses sains mampu melatih siswa dalam mengembangkan rasa tanggung jawab dan meningkatkan betapa pentingnya metode penelitian dalam proses pembelajaran (Ongowo \& Indoshi, 2013). Selain itu, dengan mengembangkan keterampilan proses sains, siswa mampu menekuni dan menelaah materi sains sesuai dengan yang telah dilakukan para ilmuwan sains. Hal ini seperti yang terdapat dalam keterampilan proses sains dasar yang meliputi pengamatan, mengelompokan atau mengkategorikan, menyimpulkan, merumuskan hipotesis, dan melakukan eksperimen (Prasasti, 2018). Guru perlu memahami keterampilan ini karena merupakan hal penting dalam pembelajaran sains (Rauf, Rasul, Mansor, Othman, \& Lyndon, 2013). Tetapi aspek-aspek dari keterampilan proses ini belum semua guru sepenuhnya mengimplementasikanya ke dalam suatu pembelajaran. Dengan pendekatan KPS satu diantaranya yaitu mampu meningkatkan keterampilan berpikir kritis siswa. Hal ini dapat membuat siswa tidak hanya mampu menghafal materi atau teori yang ada, namun juga 
mampu mengembangkan konsep dan terampil dalam bidang psikomotoriknya. Hal ini didukung dengan hasil penelitian yang dilakukan oleh Putra, Jalmo, \& Marpaung (2015) yang menunjukkan bahwa penggunaan keterampilan proses sains berpengaruh terhadap peningkatan keterampilan berpikir siswa dengan teknik uji coba pada materi pokok struktur dan fungsi bagian tumbuhan. Maka dari itu, keterampilan proses sains sangat penting bagi siswa karena mampu membekali siswa salah satunya dalam keterampilan dasar siswa. Adapun keterampilan proses sains dasar, yaitu keterampilan mengamati, mengklasifikasi, mengukur, merumuskan hipotesis, mengkomunikasikan, dan menyimpulkan.

Hal ini relevan dengan penelitian yang dilakukan oleh Hamadi (2018) yang menujukkan bahwa guru yang memiliki pemahaman tentang KPS sebanyak 50\% dan $50 \%$ guru memiliki tingkat pemahaman yang cukup. Guru telah melakukan kegiatankegiatan yang mengajak siswa kearah pengembangan KPS. Aspek KPS sudah diterapkan tetapi belum maksimal karena kurangnya waktu belajar mengajar, belum memiliki laboratorium dan lembar kerja siswa, dan rendahnya motivasi siswa. Penelitian yang dilakukan Sayekti \& Kinasih (2017) menunjukkan bahwa perencanaan penanaman KPS sudah tertuang pada RPP yang disusun oleh guru, tetapi proses penanaman KPS masih terbatas pada keterampilan mengamati dan mengkomunikasikan saja. Hal ini dikarenakan guru masih menitikberatkan pada aspek kognitif siswa.

Berdasarkan masalah tersebut, peneliti melakukan penelitian yang berkaitan dengan bagaimana penanaman keterampilan sains pada sekolah dasar. Namun, peneliti lebih spesifik membahas tentang profesionalisme guru dalam menanamkan keterampilan proses sains pada pembelajaran IPA di Ma'arif Bego pada siswa kelas V. Dalam hal ini yaitu bagaimana rancangan guru dalam mengimplentasikan KPS, perencanaan guru dalam rencana implementasi KPS, teknik penanaman KPS, dan faktor penunjang dan penghambat yang dirasakan guru dalam mengimplementasikan KPS di MI. Alasan peneliti tertarik untuk meneliti profesionalisme guru dalam menanamkan keterampilan proses sains pada pembelajaran IPA yaitu masih banyak guru yang belum memiliki pemahaman yang cukup tentang KPS hal ini akan berpengaruh terhadap penguasaan konsep kognitif siswa. Kelas V dipilih karena berdasarkan usia. Pada usia seperti itu siswa sudah mampu memahami dan mudah dalam menerima materi yang telah diberikan oleh guru.

\section{Metode Penelitian}

Jenis penelitian yang digunakan pada penelitian ini yaitu penelitian kualitatif dengan rancangan naratif. Penelitian ini dilaksanakan di MI Ma'arif Bego. Adapun subjek utama dalam penelitian ini yaitu siswa kelas $\mathrm{V}$ dan salah satu guru yang mengajar pada kelas tersebut. Proses mengumpulan data pada penelitian ini yaitu observasi, wawancara, dan dokumentasi. Menurut Riduwan (2014), observasi merupakan salah satu teknik pemgumpulan data dengan melakukan pengamatan secara langsung pada objek yang diteliti. Dalam hal ini dengan pengamatan proses pembelajaran IPA pada kelas V MI Ma'arif Bego. Sedangkan menurut Creswell (2015), wawancara terjadi ketika peneliti menanyakan berbagai pertanyaan terbuka kepada partisipan dan mencatat jawaban mereka. Wawancara pada penelitian ini dilakukan untuk menayakan bagaimana persiapan guru dalam menanamkan KPS dalam pembelajaran. Dokumentasi dalam penelitian ini berupa rencana pelaksanaan pembelajaran dan dokumen lain yang dapat mendukung penelitian. 
Penelitian ini menggunakan metode analisis data secara deskriptif yang bersifat induktif. Hal ini dikarenakan peneliti melakukan analisis tentang data yang sudah diperoleh. Analisis data dilaksanakan secara berkesinambungan mulai dari awal penelitian sampai selesai. Adapun aktivitas yang dilakukan dalam analisis data yaitu reduksi data, penyajian data, dan pengambilan kesimpulan/verifikasi (Miles \& Huberman, 1992).

\section{Hasil dan Pembahasan}

Menurut Rezba dalam Widayanti (2016), ada beberapa klasifikasi keterampilan proses sains dasar dalam pembelajaran IPA di SD/MI, yaitu meliputi keterampilan mengobservasi, keterampilan mengklasifikasi, keterampilan mengukur, keterampilan mengkomunikasikan, keterampilan menginferensikan, dan keterampilan memprediksikan. Adapun aspek dan indikator dari KPS dapat kita lihat pada tabel berikut:

Tabel 1. Keterampilan Proses Sains Dasar

\begin{tabular}{ccl}
\hline No. & Aspek KPS & \multicolumn{4}{c}{ Indikator } \\
\hline 1. & Observasi & $\begin{array}{l}\text { Mampu menggunakan semua indera yang dimilki agar bisa } \\
\text { membedakan tekstur, bau, warna, bentuk ukuran, dan lain- } \\
\text { lain, sehingga mudah dalam mengidentifikasikan, menamai, } \\
\text { dan mengamati kejadian yang sedang diobservasi dengan } \\
\text { akurat agar mendapatkan hasil sesuai dengan yang } \\
\text { diharapkan. }\end{array}$ \\
\hline 2. & Klasifikasi & $\begin{array}{l}\text { Mampu mengelompokkan, menentukan perbedaan, dan } \\
\text { mencari kesamaan terhadap suatu objek atau benda. }\end{array}$ \\
\hline 3. & Pengukuran & $\begin{array}{l}\text { Mampu memilih, menggunakan, dan menerapkan cara } \\
\text { perhitungan dengan mengunakan alat-alat ukur dengan baik } \\
\text { dan benar. }\end{array}$ \\
\hline 4. & Inferensi & $\begin{array}{l}\text { Mampu membuat suatu kesimpulan tentang hasil pengamatan } \\
\text { dari suatu masalah atau peristiwa. }\end{array}$ \\
\hline 5. & Prediksi & $\begin{array}{l}\text { Mampu memperkirakan atau menduga-duga tentang kejadian } \\
\text { yang akan terjadi berdasarkan konsep atau fakta dalam sebuah } \\
\text { ilmu pengetahuan. }\end{array}$ \\
\hline 6. & Komunikasi & $\begin{array}{l}\text { Mampu mengkomunikasikan dan menghimpun informasi } \\
\text { yang terdapat dalam grafik, tabel, dan lain-lain yang berfungsi } \\
\text { untuk menjelaskan suatu peristiwa atau kejadian secara rinci. }\end{array}$ \\
\hline
\end{tabular}

MI Ma'arif Bego sudah sepenuhnya menggunakan kurikulum 2013 pada mata pelajaran IPA dan sudah di integrasikan dengan bidang lain seperti Bahasa Indonesia, IPS, dan matematika. Semua mata pelajaran atau bidang ilmu tersebut sudah digabung ke dalam sebuah pendekatan tematik. Penelitian ini dibatasi pada pada tema 9 subtema 3 pembelajaran 2 dengan KD 3.9 mengelompokkan materi dalam kehidupan sehari-hari berdasarkan komponen penyusunan (zat tunggal dan campuran) dan 4.9 melaporkan hasil pengamatan sifat-sifat campuran dan komponen penyusun dalam kehidupan sehari-hari. Peneliti mendapatkan data melalui wawancara, observasi, dan dokumentasi.

Hasil penelitian yang terbagi menjadi beberapa aspek. Aspek yang pertama adalah cara seorang guru dalam membuat suatu rencana penanaman KPS pada siswa. 
Berkaitan dengan perencanaan proses penanaman KPS, guru menjelaskan atau memaparkannya ke dalam sebuah rencana pelaksanaan pembelajaran. RPP yang dibuat oleh guru sesuai dengan standar yang telah ditetapkan dalam standar proses pendidikan pada ketentuan Permendikbud tahun 2016 nomor 22. Dalam kegiatan pembelajaran, guru merencanakan menggunakan metode blended learning untuk menjelaskan materi yang dipelajari dan melakukan proses tanya jawab sebelum melakukan praktikum. Dalam rancangan pembelajaran tersebut terlihat aspek keterampilan proses sains yang ingin ditanamkam kepada siswa.

Guru juga merencakan pemberian fasilitas kepada siswa dalam melakukan sebuah percobaan tentang cara pencampuran homogen dan heterogen. Kemudian, siswa diberi kesempatan untuk membuat suatu kesimpulan dari hasil observasi dan praktikum yang siswa lakukan. Melalui diskusi, guru mempersiapkan suatu pembahasan yang dapat memancing wawasan siswa agar menimbulkan ide-ide atau gagasan baru. Hal ini dapat melatih siswa berpikir kritis, menganalisis, dan menyelesaikan suatu masalah dengan berani tanpa ada rasa takut. Dalam menguraikan sebuah kesimpulan, siswa diarahkan untuk membuat laporan dari hasil percobaan dan mempresentasikan hasil kerjanya secara individu atau kelompok.

Berdasarkan hasil wawancara dengan guru, diperoleh bahwa guru sudah merancang pembelajaran dengan menanamkan keterampilan proses dengan baik. Hal ini dapat dilihat pada RPP yang sudah dirancang guru tentang penanaman KPS. Guru menginginkan siswa terlibat aktif, banyak berpartisipasi, dan mendapatkan pengalaman langsung dalam kegiatan pembelajaran agar siswa mampu menguasai konsep dan memahami dengan baik mengenai materi yang dipelajari. Dalam hal ini melalui kegiatan praktik, diskusi, dan juga guru mempersiapkan fasilitas pembelajaran agar menggali bakat atau keterampilan siswa secara individu bahkan kelompok. Dan ini sesuai dengan Permendikbud nomor 23 tahun 2016 yang menjelaskan bahwa penyusunan RPP guru harus merancang pembelajaran yang memfokuskan pada siswa untuk mendorong semangat belajar, motivasi, minat, dan keterampilan siswa (Kemendikbud, 2016).

Setelah guru menjelaskan materi yang dipelajari, guru dan siswa memulai praktikum dengan melakukan sebuah percobaan tentang cara pencampuran homogen dan heterogen, karena praktikum sangat penting bagi siswa. Menurut bapak Jono yang merupakan guru di kelas V, salah satu cara dalam menanamkan KPS yaitu guru harus merencanakan suatu pembelajaran yang menarik, baik itu dari metode pembelajaran, strategi, maupun teknik pembelajaran, karena dapat mempengaruhi minat belajar siswa. Adapun salah satu metode yang efektif untuk digunakan dalam pembelajaran IPA adalah metode praktikum. Dengan metode praktikum siswa dituntut untuk melakukan suatu praktik atau percobaan yang akan membuat siswa lebih paham tentang materi dan menuntut siswa terlibat langsung dalam pembelajaran. Hal ini sangat baik untuk menanamkan keterampilan proses sains dalam diri siswa. Selaras dengan ungkapan subali dalam Sayekti \& Kinasih (2017) yang menyatakan bahwa dalam melakukan kegiatan-kegiatan yang berkaitan dengan investigasi dalam pembelajaran IPA, diperlukan untuk melakukanya secara terbuka, agar siswa menjadi lebih leluasa dalam mengembangkan kemampuannya, lebih kreatif dalam menciptakan sesuatu, dan terbiasa melakukan kegiatan-kegiatan investigasi seperti yang dilakukan para ilmuan dalam melakukan penemuan secara ilmiah. Hodson dalam Ulfa (2016) juga mengatakan bahwa kegunaan praktikum dalam pembelajaran IPA yaitu: (1) Memotivasi siswa dan merangsang minat serta hobinya, (2) Mengajarkan keterampilan-keterampilan yang 
harus dilakukan di labolatorium, (3) Membantu perolehan dan pengembangan konsep, (4) Menanamkan sikap ilmiah, dan (5) Mengembangkan sebuah konsep IPA dan mengembangkan keterampilan-keterampilan dalam pelaksanaan IPA tersebut.

Rencana yang dilakukan oleh guru pada kegiatan pengamatan, mengkomunikasikan, dan menyimpulkan terlihat ketika siswa diperintahkan untuk mengamati tentang benda-benda yang dicampuri salah satunya, seperti air dan minyak. Demonstrasi dari guru tentang campuran heterogen dan campuran homogen dengan menjelaskan tentang definisi campuran heterogen dan campuran homogen beserta contohnya. Dalam keterampilan mengkomunikasikan, guru memberikan kesempatan kepada siswa untuk menyampaikan hasil kerja secara individu bahkan kelompok dan menguraikan kesimpulan tentang hasil pengamatan dan praktikum yang sudah dilakukan.

Dalam melakukan suatu pembelajaran dengan pendekatan KPS ada beberapa aspek yang harus dipahami oleh seorang guru dalam mengaplikasikan KPS dalam pembelajaran yaitu suatu pembelajaran harus berpusat pada siswa. Hal ini akan mengembangkan keterampilan siswa yaitu meliputi KPS dasar diantaranya mengobservasi, merancang, dan melaksanakan penelitian, serta mengkomunikasikan hasil investigasinya (Sayekti \& Kinasih, 2017). Selain itu, keterampilan proses dapat mengembangkan kognitif siswa yang timbul dari proses dialektika, karena dengan pengalaman yang didapatkan akan digunakan untuk saling berbagi dengan orang lain (Prasasti, 2018). Dengan hal ini seorang guru harus lebih menguasai dan kreatif dalam menggunakan pendekatan KPS.

Aspek yang kedua adalah teknik penanaman KPS. Penerapan KPS pada siswa kelas $\mathrm{V}$ dapat dilakukan dengan cara memberikan kesempatan kepada siswa dalam beberapa kegiatan pembelajaran. Hal ini terlihat ketika guru memfasilitasi kegiatan pengamatan saat proses mencampurkan salah satu bahan seperti susu bubuk dan air dan bagaimana perubahannya. Hal ini dilakukan untuk menanamkan keterampilan mengamati. Guru juga memberikan kesempatan kepada siswa untuk mengamati perbedaan suatu benda ketika sebelum dicampur dan sesudah dicampur baik itu dengan penglihatan, sentuhan, dan perasaan. Siswa juga diberikan waktu dan kesempatan untuk menyampaikan hasil diskusi baik individu bahkan kelompok. Ini merupakan bagian dari aspek komunikasi dalam KPS.

Dilihat dari perencanaan yang dilakukan guru dalam menanamkan KPS, konsep dan teknik-teknik yang sudah dirancang sudah mencapai standar minimal, karena guru telah menggunakan metode-metode yang menunjang keberhasilan suatu pembelajaran, seperti ceramah, tanya jawab, dan praktikum. Walaupun ada beberapa yang direncanakan tidak teraplikasikan dalam pembelajaran. Dengan metode diskusi dan tanya jawab, guru mampu menanamkan kemampuan siswa dalam berkomunikasi dan menyampaikan suatu ide atau gagasan tentang masalah yang dipelajari. Pada tahap diskusi, siswa dibagi menjadi beberapa kelompok yang beranggotakan 4 hingga 5 siswa.

Metode praktikum membantu siswa untuk terjun langsung dan mendapatkan pengalaman dalam suatu pembelajaran agar siswa lebih menghayati proses atau kegiatan yang sedang dilakukan. Praktikum dapat mengembangkan keterampilan kognitif siswa, teori yang sudah dipelajari akan lebih dipahami dan dimengerti oleh siswa, dan siswa lebih menghayati proses yang sedang dilakukan melalui kegiatan langsung. Sedangkan, metode demonstrasi membantu siswa dalam mengembangkan kemampuan mengamati. Meskipun metode ceramah mendominasi, tetapi itu perlu untuk memperjelas materi yang dipelajari. 
Pada tahap evaluasi pembelajaran, guru membiasakan siswa mengadakan review setiap akhir pembelajaran, agar pelajaran yang sudah dipelajari lebih memahami lagi. Guru mengadakan review dengan cara melemparkan pertanyaan kepada siswa tentang materi yang telah dipelajari. Berdasarkan pemaparan yang sudah dijelaskan tersebut, dapat disimpulkan bahwa aspek KPS yang ditanamkan kepada siswa hanya terpaku pada kemampuan mengamati dan mengkomunikasikan.

Dalam pendekatan tematik, terdapat tiga aspek penilain yaitu kognitif, afektif, dan psikomotorik. Ketiga ranah tersebut harus tercantum semua dalam suatu pembelajaran, tetapi guru biasanya hanya menilai atau memfokuskan penilaian pada aspek kognitif dan kecerdasan berargumen siswa selama pembelajaran. Walaupun aspek yang lain juga dinilai, tetapi aspek kognitif lebih mendominasi karena evaluasi akhir pembelajaran atau hasil akhir dari semua proses pembelajaran hanya akan membutuhkan nilai kognitif semata. Hal tersebut berakibat karena pemahaman guru terhadap keterampilan proses sains yang masih terbatas dan kurang optimal dalam memanajemen waktu.

Pada aspek penilaian guru tidak hanya menitikberatkan pada penilaian pengetahuan saja tetapi ketiga aspek penilaian itu harus berkaitan semua. Hal ini selaras dengan sistem penilaian pembelajaran dalam kurikulum 2013 yang menyebutkan bahwa penilaian hasil belajar siswa pada pendidikan dasar harus meliputi tiga aspek kognitif, afektif, dan psikomotorik dan penilaian juga harus berkesinambungan dan menyeluruh. Dalam melaksanakan penilaian KPS, dibutuhkan berbagai cara atau teknik yang sesuai dengan hakikat sains itu sendiri. Hal ini seperti yang dipaparkan Arif (2016) yang menyatakan bahwa dalam pembelajaran sains harus melakukan evaluasi dengan memperhatikan teknik-teknik yang berkaitan dengan hakekat sains, agar seorang guru mampu mengetahui sejauh mana keberhasilan dalam suatu pembelajaran dan kemampuan siswa dalam proses pembelajaran. Pada penilaian sains, penilaian yang digunakan harus berfokus pada proses bukan pada produk sains. Seperti halnya bagaimana keaktifan siswa ketika dalam pembelajaran, penilaian bukan hanya keaktifan berbicara tetapi kemampuan siswa dalam menemukan ide atau gagasan baru dalam sebuah pembelajaran.

Dalam menggunakan pendekatan KPS, ada beberapa aspek yang harus timbul dalam kegiatan pembelajaran. Aspek penanaman KPS dilihat dari beberapa indikator, yaitu yang pertama indikator pada aspek pengamatan yang dimunculkan tentang cara siswa memanfaatkan indra penglihatan untuk mengobservasi bentuk perubahan pada benda yang sudah tercampur dan untuk mengamati bagaimana perbedaan benda ketika sesudah dicampur dan sebelum dicampur.

Adapun indikator pada aspek mengklasifikasikan sebagian besar sudah tampak dalam pembelajaran. Pada aspek ini siswa diminta melengkapi tabel tentang perbedaan campuran heterogen dan campuran homogen serta mengidentifikasi contohnya dalam kehidupan sehari-hari. Pada aspek keterampilan siswa diminta mempraktikkan cara mencampurkan dua benda tunggal dan benda campuran yang telah disediakan oleh guru. Hal ini dilakukan agar siswa dapat berlatih dalam meningkatkan keterampilan sebagai implementasi dari pengetahuan yang sudah mereka pelajari sebelumnya.

Sedangkan keterampilan memprediksi, siswa tidak mendapatkan kesempatan untuk memprediksi tentang pengamatan yang dilakukan mengenai campuran benda tunggal dan benda campuran. Padahal banyak kasus yang bisa dimunculkan oleh guru untuk mengekspor kemampuan siswa dalam memprediksi materi ini. Pada aspek menyimpulkan, siswa diberi kesempatan untuk menginferensikan tentang materi yang 
dipelajari. Pada aspek mengkomunikasikan, siswa diberikan kesempatan untuk menyampaikan hasil penemuan mereka, seperti pada saat diskusi kelompok, siswa menyampaikan gagasan dan argumennya.

Dari data-data yang ada, proses penanaman KPS pada pembelajaran IPA materi zat tunggal dan zat campuran sudah baik walaupun tidak maksimal karena pada materi ini, guru sudah menimbulkan kegiatan-kegiatan yang memicu siswa dalam menumbuhkan KPS, walaupun ada beberapa aspek KPS yang belum ada, seperti merumuskan hipotesis, aplikasi konsep, dan lain sebagainya. KPS sangat penting untuk diimplementasikan dalam pembelajaran. Guru juga harus berusaha memunculkan kegiatan-kegiatan yang memicu semangat belajar siswa dan menumbuhkan aspek KPS dalam pembelajaran. Dalam pembelajaran IPA, keterampilan proses sains sangat penting dan harus dikembangkan yaitu dengan cara menggunakan metode atau strategi yang mendukung contohnya metode diskusi, tanya jawab, demostrasi, pengamatan yang sederhana, dan metode-metode lainya yang mendukung, agar memberikan kesempatan kepada siswa dalam mengasah KPS tersebut dan juga agar siswa mampu bersikap atau bertindak dan mampu memperlihatkan karakter yang dimilikinya. Maka dari itu, guru harus pandai dalam memilih metode atau strategi pembelajaran supaya tujuan pembelajaran sesuai dengan hakikat sains yang sebenarnya.

Hasil penemuan yang diamati oleh peneliti dalam penanaman KPS oleh guru mulai dari perencanaan sampai kegiatan belajar mengajar sudah baik. Dalam perencanaan, guru sudah mencantumkan beberapa aspek KPS ke dalam RPP, yang diantaranya mengobservasi, mengkomunikasi, mengklasifikasikan, dan menyimpulkan. Sedangkan pada proses kegiatan pembelajaran, kegiatan KPS yang ada didalam RPP sudah semua dilakukan walaupun didominasi oleh kegiatan mengamati dan mengkomunikasi. Ada beberapa metode pembelajaran dan kegiatan RPP yang tidak terealisasikan dalam pembelajaran yang diakibatkan oleh keterbatasan waktu atau guru kesulitan dalam mengatur waktu dalam pembelajaran dan kurangnya pemahaman guru tentang KPS tersebut. Masalah tersebut menjadi faktor penghambat bagi guru dalam menanamkan KPS terhadap siswa.

\section{Simpulan}

Dari hasil penelitian dan pembahasan, disimpulkan bahwa dalam RPP yang dibuat oleh guru sudah mencantumkan beberapa aspek KPS, tetapi semua aspek yang ada didalam RPP belum sepenuhnya diimplementasikan. Terdapat 15 Aspek KPS, untuk KPS dasar terdapat 6 aspek yang harus di terapkan oleh guru tetapi pada pembelajaran sains di MI Ma'arif Bego hanya 4 aspek KPS saja yang dominan muncul, yaitu observasi, mengkomunikasikan, mengklasifikasikan, dan menyimpulkan. Hal ini dikarenakan kurangnya pemahaman guru terhadap KPS tersebut.

\section{Daftar Pustaka}

Arif, M. (2016). Pengembangan Instrumen Penilaian Mapel Sains melalui Pendekatan Keterampilan Proses Sains SD/MI. TA'ALLUM, 4(1), 123-148. https://doi.org/ 10.21274/taalum.2016.4.1.123-148

Creswell J. W. (2015). Riset Pendidikan, Perencanaan, Pelaksanaan, dan Evaluasi Riset Kualitatif dan Kuantitatif. Yogyakarta: Pustaka Pelajar.

Elvanisi, A., Hidayat, S., \& Fadillah, E. N. (2018). Analisis Keterampilan Proses Sains Siswa Sekolah Menengah Atas. Jurnal Inovasi Pendidikan IPA, 4(2), 245-252. 
https://doi.org/10.21831/jipi.v4i2.21426

Hamadi, A. A. L. (2018). Pemahaman Guru terhadap Keterampilan Proses Sains (KPS) dan Penerapannya dalam Pembelajaran IPA SMP di Salatiga. Edu Sains: Jurnal Pendidikan Sains \& Matematika, 6(2), 42-53. https://doi.org/10.23971/eds.v6i2. 935

Hasanah, A., \& Utami, L. (2017). Pengaruh Penerapan Model Problem Based Learning terhadap Keterampilan Proses Sains Siswa. Jurnal Pendidikan Sains (JPS), 5(2), 56-64. https://doi.org/10.26714/jps.5.2.2017.56-64

Kemendikbud. (2016). Permendikbud Nomor 23 Tahun 2016 Standar Penilaian Pendidikan. Jakarta: Kemendikbud.

Miles, M. B., \& Huberman, A. M. (1992). Analisis Data Kualitatif tentang MetodeMetode Baru (Terjemahan). Jakarta: Universitas Indonesia Press.

Ongowo, R. O., \& Indoshi, F. C. (2013). Science Process Skills in the Kenya Certificate of Secondary Education Biology Practical Examinations. Creative Education, 4(11), 713-717. https://doi.org/10.4236/ce.2013.411101

Prasasti, P. A. T. (2018). Efektivitas Scientific Approach with Guided Experiment pada Pembelajaran IPA untuk Memberdayakan Keterampilan Proses Sains Siswa Sekolah Dasar. Profesi Pendidikan Dasar, 1(1), 19-26. https://doi.org/10.23917/ ppd.v1i1.3623

Putra, W. G., Jalmo, T., \& Marpaung, R. R. T. (2015). Pengaruh Penggunaan Keterampilan Proses Sains dalam Meningkatkan Keterampilan Berpikir Kritis Siswa. Jurnal Bioterdidik Wahana Ekspresi Ilmiah, 3(6), 1-11. Retrieved from http:/jurnal.fkip.unila.ac.id/index.php/JBT/article/view/9423

Rauf, R. A. A., Rasul, M. S., Mansor, A. N., Othman, Z., \& Lyndon, N. (2013). Inculcation of Science Process Skills in A Science Classroom. Asian Social Science, 9(8), 47-57. https://doi.org/10.5539/ass.v9n8p47

Riduwan. (2014). Metode Riset. Jakarta: Rineka Cipta.

Sayekti, I. C., \& Kinasih, A. M. (2017). Kemampuan Guru Menerapkan Keterampilan Proses Sains dalam Pembelajaran IPA pada Siswa Sekolah Dasar. Profesi Pendidikan Dasar, 4(1), 97-105. https://doi.org/10.23917/ppd.v1i1.4464

Ulfa, S. W. (2016). Pembelajaran Berbasis Praktikum: Upaya Mengembangkan Sikap Ilmiah Siswa pada Pembelajaran Biologi. NIZHAMIYAH, 6(1), 65-75. Retrieved from http://dx.doi.org/10.30821/niz.v6i1.29

Widayanti, E. Y. (2016). Penguasaan Keterampilan Proses Sains Dasar Siswa Madrasah Ibtidaiyah (Studi pada Madrasah Mitra STAIN Ponorogo). Kodifikasia: Jurnal Penelitian Islam, 9(1), 171-198. https://doi.org/10.21154/kodifikasia.v9i1.465 